\title{
PEMODELAN KLASIFIKASI DALAM MENINGKATKAN PROSES PEMILIHAN CALON KARYAWAN DENGAN METODE C4.5 DAN JARINGAN SYARAF TIRUAN
}

\author{
Henny Leidiyana ${ }^{1}$, Angga Aditya Permana ${ }^{2}$ \\ ${ }^{1}$ Program Studi Teknik Informatika, Fakultas Teknologi Informasi \\ Universitas Bina Sarana Informatika \\ ${ }^{2}$ Program Studi Teknik Informatika, Fakultas Teknik \\ Universitas Muhammadiyah Tangerang \\ Jl. Perintis Kemerdekaan 1/33 Cikokol Kota Tangerang TLP. 55793251 \\ Email : henny.hnl@ bsi.ac.id ${ }^{1}$, anggaumt@gmail.com ${ }^{2}$
}

\begin{abstract}
Abstrak
Bagi manajemen SDM dalam sebuah perusahaan, pemilihan sumber daya manusia yang memiliki kualifikasi dan kinerja yang tinggi merupakan tugas yang penting. Pelamar kerja dengan jumlah yang sangat banyak membuat manajemen SDM harus melakukan pemilihan calon karyawan dengan teliti dan membutuhkan waktu yang tidak sedikit. Bidang penambangan data yang saat ini sedang populer, dapat dimanfaatkan untuk meningkatkan kinerja pemilihan karyawan. Dalam penulisan ini, dibahas tentang penerapan algoritma $\mathrm{C4.5}$ dan jaringan syaraf tiruan untuk membuat model klasifikasi pemilihan karyawan. Untuk menguji model yang dihasilkan, beberapa percobaan dilakukan dengan menggunakan data yang dikumpulkan dari sebuah cabang perusahaan. Model yang dihasilkan dapat digunakan untuk membantu SDM dalam meningkatkan hasil pemilihan pelamar baru.
\end{abstract}

Kata Kunci : Karyawan, Jaringan Syaraf Tiruan, C4.5

\section{Abstract}

For HR management in a company, the selection of human resources who have high qualifications and performance is an important task. A very large number of job applicants make HR management have to carefully select prospective employees and require a lot of time. The field of data mining that is currently popular, can be used to improve employee selection performance. In this paper, it discusses the application of the C4.5 algorithm and neural networks to create a classification model for employee selection. To test the resulting model, several experiments were carried out using data collected from a branch company. The resulting model can be used to help HR improve the results of the selection of new applicants.

Keyword : Resources, neural network, 44.5

\begin{abstract}
PENDAHULUAN
Hampir semua manajer dalam perusahaan, sumber daya manusia tmenjadi salah satu perhatian utama. Oleh sebab itu perusahaan tertarik untuk melakukan pemilihan karyawan secara tepat. Setelah merekrut karyawan, manajemen memperhatikan dengan kinerja karyawan ini untuk ditempatkan pada tempat yang sesuai. Penambangan data adalah bidang penemuan informasi dan pengetahuan yang baru dan handal (Han et al., 2011). Penambangan data memiliki beberapa tugas seperti asosiasi rule mining, klasifikasi dan prediksi, dan clustering.
\end{abstract}

Penambangan Data (Witten, 2011) didefinisikan sebagai proses penemuan pola dalam data. Berdasarkan tugasnya, penambangan data dikelompokkan menjadi (Larose, 2005) deskripsi, estimasi, prediksi, klasifikasi, clustering, Asosiasi. Proses dalam tahap data

klasifikasi. Proses kedua adalah klasifikasi, dimana data tes digunakan untuk memperkirakan akurasi dari rule klasifikasi. (Han, 2006). Proses klasifikasi didasarkan pada empat komponen: (Gorunescu, 2011)

a. Kelas

Variabel dependen yang berupa kategorikal yang merepresentasikan 
'label' yang terdapat pada objek. Contohnya: resiko penyakit jantung, resiko kredit, customer loyalty, jenis gempa.

b. Predictor

Variabel independen yang direpresentasikan oleh karakteristik (atribut) data. Contohnya: merokok, minum alkohol, tekanan darah, tabungan, aset, gaji.

c. Training dataset

Satu set data yang berisi nilai dari kedua komponen di atas yang digunakan untuk menentukan kelas yang cocok berdasarkan predictor.

d. Testing dataset

Berisi data baru yang akan diklasifikasikan oleh model yang telah dibuat dan akurasi klasifikasi dievaluasi

\section{TINJAUAN PUSTAKA}

\section{Metode C4.5}

J. Ross Quinlan, seorang peneliti di bidang machine learning, membuat 1 . sebuah algoritma decision tree yang dikenal dengan ID3 (Iterative Dichotomiser). Quinlan kemudian membuat algoritma C4.5 (sering disebut dengan pohon keputusan) yang merupakan pengembangan dari algoritma 2 ID3 (Han, 2006). Algoritma ini memiliki kelebihan, yaitu mudah dimengerti, fleksibel, dan menarik karena dapat divisualisasikan dalam bentuk gambar 3 . (pohon keputusan) (Gorunescu, 2011). Algoritma C4.5 merupakan struktur pohon dimana terdapat simpul yang mendeskripsikan atribut-atribut, setiap cabang menggambarkan hasil dari atribut yang diuji, dan setiap daun menggambarkan kelas. Algoritma C4.5 1 . secara rekursif mengunjungi setiap simpul keputusan, memilih pembagian yang optimal, sampai tidak bisa dibagi lagi. Algoritma C4.5 menggunakan konsep information gain atau entropy reduction untuk memilih pembagian yang optimal (Han, 2006).

\section{Jaringan Syaraf Tiruan}

Neural network adalah (Han, 2006) satu set unit input/output yang terhubung dimana tiap relasinya memiliki bobot. Sejak tahun 1950-an, neural network telah digunakan untuk tujuan prediksi, bukan hanya klasifikasi tapi juga untuk regresi dengan atribut target kontinu (Vercellis, 2009).

Multilayer perceptron (MLP) disebut juga multilayer feedforward neural network merupakan algoritma yang paling luas digunakan. Menurut Wong, Bodnovich dan Selvi (1997), sekitar 95\% aplikasi bisnis yang menggunakan neural network, memakai algoritma ini (Vecellis, 2009). Salah satu kelebihan neural network adalah cukup baik dalam menangani data yang mengandung noise (Larose, 2005).

MLP terdiri dari input layer, satu atau lebih hidden layer, dan output layer. Berikut penjelasan masing-masing layer: (Vercellis, 2009)

\section{Input layer \\ Input layer untuk menerima nilai masukan dari tiap record pada data. Jumlah simpul input sama dengan jumlah variabel prediktor.}

\section{Hidden layer}

Hidden layer mentransformasikan nilai input di dalam network.

\section{Output layer \\ Garis yang terhubung dengan Output layer berasal dari hidden layer atau input layer dan mengembalikan nilai keluaran yang bersesuaian dengan variabel prediksi.}
Metode Evaluasi dan Validasi Algoritma Klasifikasi Penambangan Data
Untuk mengukur akurasi algoritma klasifikasi, metode yang dapat digunakan antara lain cross validation dan confusion matrixUntuk mengembangkan aplikasi (development) berdasarkan model yang dibuat, digunakan Rapid Miner.

1. Cross Validation

Cross validation adalah pengujian standar yang dilakukan untuk memprediksi error 
rate. Data training dibagi secara random ke dalam beberapa bagian dengan perbandingan yang sama kemudian error rate dihitung bagian demi bagian, selanjutnya hitung rata-rata seluruh error rate untuk mendapatkan error rate secara keseluruhan.

\section{Confusion matrix}

Metode ini menggunakan tabel matriks seperti padaTabel 1 jika data set hanya terdiri dari dua kelas, kelas yang satu dianggap sebagai positif dan yang lainnya negatif (Bramer, 2007).

Tabel 1 Model Confusion Matrix (Bramer, 2007)

\begin{tabular}{lll}
\hline Klasifikasi & \multicolumn{2}{c}{ Diklasifikasikan } \\
yang benar & \multicolumn{2}{c}{ sebagai } \\
\cline { 2 - 3 } & \multicolumn{1}{c}{+} & \multicolumn{1}{c}{-} \\
\hline+ & true & false \\
& positives & negatives \\
- & false & true \\
& positives & negatives \\
\hline
\end{tabular}

True positives adalah jumlah record positif yang diklasifikasikan sebagai positif, false positives adalah jumlah record negatif yang diklasifikasikan sebagai positif, false negatives adalah jumlah record positif yang diklasifikasikan sebagai negatif, true negatives adalah jumlah record negatif yang diklasifikasikan sebagai negative, kemudian masukkan data uji. Setelah data uji dimasukkan ke dalam confusion matrix, hitung nilai-nilai yang telah dimasukkan tersebut untuk dihitung jumlah sensitivity (recall), specificity, precision dan accuracy. Sensitivity digunakan untuk membandingkan jumlah TP terhadap jumlah record yang positif sedangkan specificity adalah perbandingan jumlah $\mathrm{TN}$ terhadap jumlah record yang negatif.

\section{HASIL DAN PEMBAHASAN}

Atribut-atribut beserta nilainya mengenai pemilihan karyawan terdapat pada tabel 2 , terdiri dari tujuh atribut prediktor dan satu atribut kelas. Pemodelan menggunakan aplikasi rapidminer.

Tabel 2. Atribut dan Nilai

\begin{tabular}{cll}
\hline No & \multicolumn{1}{c}{ Atribut } & \multicolumn{1}{c}{ Nilai } \\
\hline 1 & Umur & muda, sedang, tua \\
& & belum menikah, \\
2 & Status & menikah, duda/janda \\
3 & Sekolah & negeri, swasta \\
4 & Jenjang & D3, S1 \\
5 & Nilai & cukup, kurang \\
6 & Pengalaman & ada, tidak ada \\
7 & domisili & sesuai, tidak \\
& & diterima, tidak \\
8 & Kesimpulan & diterima \\
\hline
\end{tabular}

Penelitian ini dilakukan terhadap pemilihan karyawan calon surveyor yang tugasnya menganalisa calon pelanggan. Penerimaan karyawan hanya untuk karyawan yang berjenis kelamin laki-laki karena pekerjaan ini merupakan pekerjaan lapangan dan dilakukan pada waktu yang tidak menentu sehingga atribut jenis kelamin tidak masuk sebagai atribut predictor. Jenjang pendidikan yang diinginkan oleh perusahaan untuk bidang pekerjaan ini adalah lulusan D3 atau S1 baik dari perguruan tinggi negeri ataupun swasta. Perusahaan ini memiliki banyak cabang sehingga atribut domisili juga menjadi atribut predictor. Pemilihan calon karyawan saat ini dilakukan dengan cara seleksi administrasi dan wawancara. Tidak ada tes lainnya. Pewawancara adalah kepala cabang. Jika memenuhi kualifikasi menurut pewawancara maka diterima. dari Data yang diperoleh sebanyak 56 data pelamar dan hasil seleksinya.

Penelitian ini menerapkan dua algoritma yaitu C4.5 dan jaringan syaraf tiruan. Kemudian dua model yang dihasilkan dari dua algoritma dibandingkan akurasinya. Gambar 1 adalah model yang dihasilkan dari algoritma C4.5. Gambar 2 adalah model yang dihasilkan dari jaringan syaraf tiruan. 


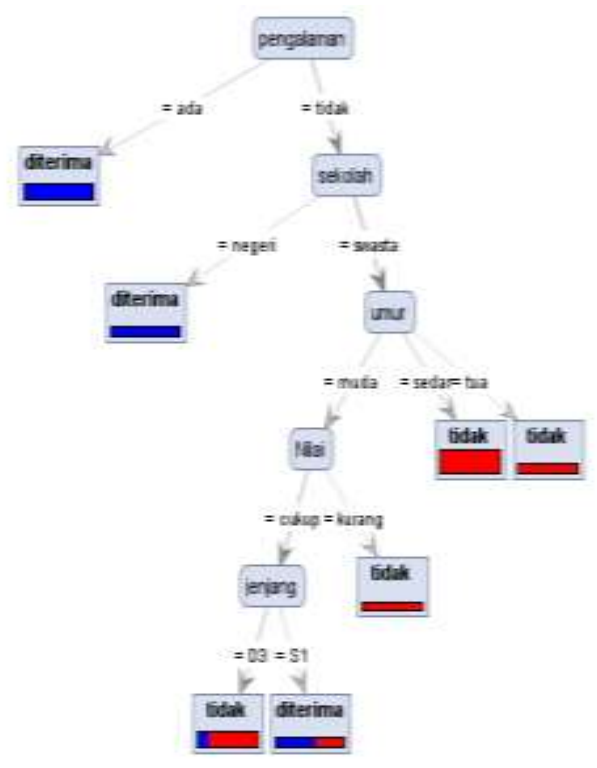

Gambar 1 Model Algoritma C4.5

Pohon yang dihasilkan dengan algoritma C4.5 adalah rule yang dapat digunakan menentukan calon karyawan yang layak diterima. Hasil penerapan dengan jaringan syaraf tiruan dapat dilihat pada keterangan di bawah Gambar 2

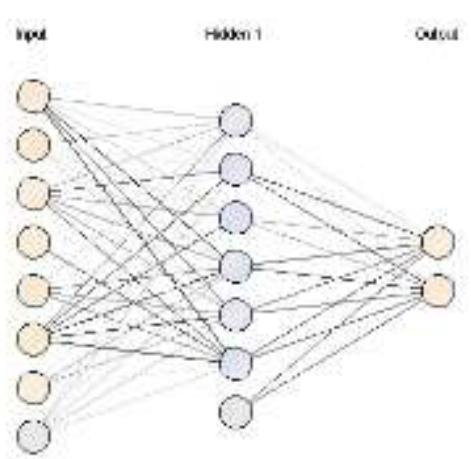

Gambar 2 Model Jaringan Syaraf Tiruan

Hidden 1

$======$

Node 1 (Sigmoid)

umur: 1.109

status: 0.857

sekolah: 1.148

jenjang: 0.286

Nilai: 0.628

pengalaman: -1.977
Domisili: -0.321

Threshold: -0.648

Node 2 (Sigmoid)

umur: -0.422

status: -0.226

sekolah: -2.075

jenjang: -0.249

Nilai: -0.131

pengalaman: 2.888

Domisili: -0.245

Threshold: 0.882

Node 3 (Sigmoid)

umur: 0.862

status: 0.442

sekolah: 1.608

jenjang: 0.203

Nilai: 0.294

pengalaman: -2.498

Domisili: 0.020

Threshold: -0.401

Node 4 (Sigmoid)

umur: 3.314

status: 0.618

sekolah: 1.783

jenjang: 0.030

Nilai: 1.719

pengalaman: -3.020

Domisili: -1.415

Threshold: -0.887

Node 5 (Sigmoid)

umur: 2.927

status: 0.669

sekolah: 1.470

jenjang: 0.080

Nilai: 1.546

pengalaman: -2.691

Domisili: -1.184

Threshold: -0.903

Node 6 (Sigmoid)

umur: 3.512

status: 0.206

sekolah: 2.746 
jenjang: -2.655

Nilai: 1.627

pengalaman: -3.295

Domisili: -0.266

Threshold: -0.608

Output

Class 'diterima' (Sigmoid)

Node 1: -0.656

Node 2: 2.701

Node 3: -1.242

Node 4: -2.609

Node 5: -2.192

Node 6: -2.536

Threshold: 2.419

Class 'tidak' (Sigmoid)

Node 1: 0.671

Node 2: -2.694

Node 3: 1.243

Node 4: 2.579

Node 5: 2.203

Node 6: 2.540

Threshold: -2.427

\section{Pengujian Algoritma}

\section{Cross Validation}

Dalam penelitian ini digunakan 10 foldcross validation dimana 56 data training dibagi secara random ke dalam 10 bagian dengan perbandingan yang sama kemudian error rate dihitung tiap bagiannya.

\section{Confusion Matrix}

Tabel confusion matrix yang dihasilkan dapat dilihat pada Gambar 3, yang merupakan hasil penerapan algoritma C4.5 dan Gambar 4 hasil penerapan jaringan syaraf tiruan.

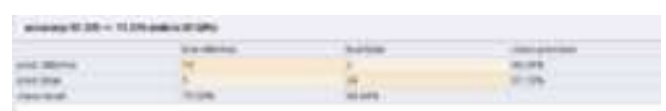

Gambar 3 Confusion Matrix untuk Algoritma C4.5
Akurasi model yang dihasilkan dengan menerapkan algoritma C4.5 sebesar $87,5 \%$ sedangkan akurasi penerapan dengan jaringan syaraf tiruan lebih besar sebesar $89,29 \%$

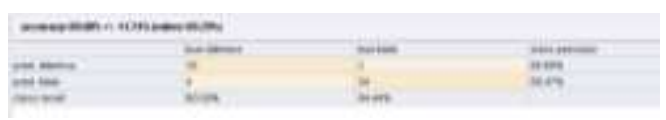

Gambar 4 Confusion Matrix untuk Jaringan syaraf tiruan

\section{KESIMPULAN}

Penelitian bertujuan untuk untuk meningkatan kualitas pemilihan calon karyawan khususnya untuk jenis pekerjaan surveyor dengan menerapkan penggalian data yang merupakan bidang yang saat ini sedang populer. Tugas penambangan data di sini adalah klasifikasi dengan membandingkan dua algoritma klasifikasi yaitu C4.5 dan jaringan syaraf tiruan. Pengujian model yang dihasilkan menggunakan metode Cross Validation dan Confusion Matrix. Berdasarkan pengujian, penerapan metode jaringan syaraf tiruan menghasilkan model yang lebih akurat dibanding C4.5. Agar model dapat digunakan secara umum, khususnya pada bidang pekerjaan ini maka sebaiknya data dikumpulkan dari berbagai cabang dari perusahaan yang sama atau bahkan dari perusahaan yang berbeda di berbagai wilayah.

\section{REFRENSI}

Al-Radaideh, Qasem A. Using Data Mining Techniques to Build a Classification Model for Predicting employees Performance. IJACSA. Vol 2 No 3. 2012 page 144

Bramer, Max. (2007). Principles of Data Mining. London: Springer

Gorunescu, Florin (2011). Data Mining: Concepts, Models, and Techniques. Verlag Berlin Heidelberg: Springer 
Han, J.,\&Kamber, M. (2006).Data Mining Concept and Tehniques.San Fransisco: Morgan Kauffman.

Kusrini\&Luthfi,E.T.(2009).Algoritma Data Mining. Yogyakarta: Andi Publishing.

Larose, D. T. (2005).Discovering Knowledge in Data. New Jersey: John Willey \& Sons, Inc.

Vercellis, Carlo (2009). Business Intelligent: Data Mining and Optimization for Decision Making. Southern Gate, Chichester, West Sussex: John Willey \& Sons, Ltd.

Witten, I. H., Frank, E., \& Hall, M. A. (2011).Data Mining: Practical Machine Learning and Tools. Burlington: Morgan Kaufmann Publisher. 